\title{
Digestion, Milk Production, Milk Composition, and Blood Composition of Dairy Cows Fed Formaldehyde Treated Flaxseed or Sunflower Seed ${ }^{1}$
}

\author{
H. V. Petit \\ Dairy and Swine Research and Development Centre \\ Agriculture and Agri-Food Canada \\ Lennoxville QC J1M 1 Z3 Canada
}

\section{ABSTRACT}

Forty midlactation Holstein cows averaging $635 \mathrm{~kg}$ of body weight $(\mathrm{SE}=8)$ were allotted at wk 25 of lactation to ten groups of four cows blocked for similar calving dates to determine the effects of formaldehyde treatment of flaxseed and sunflower seed on fatty acid composition of blood and milk, milk yield, feed intake, and apparent digestibility. Cows were fed a total mixed diet based on grass silage and supplements for ad libitum intake over a 10 -wk period. Cows within each block were assigned to one of the four isonitrogenous supplements based on either untreated whole flaxseed, formaldehyde-treated whole flaxseed, untreated whole sunflower seed, or formaldehyde-treated whole sunflower seed. Cows fed whole flaxseed compared with sunflower seed maintained greater dry matter (DM) intake (20.3 vs. $18.9 \mathrm{~kg} / \mathrm{d}$ ). Intake of DM, expressed as a percentage of body weight, was increased by adding formaldehyde to oilseeds (3.24 vs. 2.98\%). Milk production was similar for cows fed flaxseed and those fed sunflower. Formaldehyde treatment of flaxseed and sunflower seed increased milk production by an average of $2.65 \mathrm{~kg} / \mathrm{d}$. Efficiency of fat-corrected milk yield per kilogram of DM intake was increased by formaldehyde treatment (1.31 vs. 1.21 ), and it was greater with sunflower seed than with flaxseed (1.33 vs.1.21). Protein concentration in milk was greater for cows fed flaxseed (3.38\%) compared with those fed sunflower seed (3.21\%) and formaldehyde had no effect. Apparent digestibility of DM was not affected by type of seed but it was greater for cows fed formaldehyde-treated seeds. Cows fed formaldehyde-treated flaxseed had the greatest apparent digestibilities of acid detergent and neutral detergent fiber compared with those fed the other diets. Apparent digestibilities of fatty acids were greater for sunflower

Received October 1, 2002.

Accepted February 12, 2003.

Corresponding author: Hélène V. Petit; e-mail: petith@agr.gc.ca

${ }^{1}$ Contribution Number 773 from the Dairy and Swine Research and Development Centre, Agriculture and Agri-Food Canada, P.O. Box 90, Lennoxville QC J1M 1Z3 CANADA. seed than for flaxseed-based diets. In general, formaldehyde treatment had limited effect on milk fatty acid composition, suggesting that formaldehyde was not very effective in protecting polyunsaturated fatty acids against ruminal biohydrogenation. Feeding flaxseed resulted in the lowest omega 6 to omega 3 fatty acid ratio. The data suggest that both flaxseed and sunflower seed are acceptable fat sources for midlactating cows and that flaxseed increases milk protein percentage compared to sunflower seed.

(Key words: flaxseed, milk production, sunflower, fatty acids)

Abbreviation key: FOFLA = supplement based on formaldehyde-treated whole flaxseed, FOSUN = supplement based on formaldehyde-treated whole sunflower seed, UNFLA = supplement based on untreated whole flaxseed, UNSUN = supplement based on untreated whole sunflower seed.

\section{INTRODUCTION}

Health-conscious consumers are demanding dairy products that are richer in mono- and polyunsaturated fatty acids. Feeding oilseeds to lactating dairy cows is one method to change the proportion of unsaturated fatty acids in milk fat with increases as high as $40 \%$ (Casper et al., 1990; Stegeman et al., 1992; Kim et al., 1993), although extensive biohydrogenation occurs normally in the rumen (Palmquist and Jenkins, 1980). Sunflower seed and flaxseed would be a good choice from a consumer viewpoint, as both are rich in polyunsaturated fatty acids, with sunflower being a source of linoleic acid (66\% of the total fatty acids), while flaxseed is rich in linolenic acid (56\% of the total fatty acids). Sunflower seeds increase the proportion of unsaturated fatty acids in milk compared to cows fed no supplemental fat (Schingoethe et al., 1996). However, Rafalowski and Park (1982) found no difference among inclusion levels of 10,20 , and $30 \%$ in the concentrate probably as a result of a relatively slowed rate of release of the fat from whole sunflower seed in the rumen. Moreover, cows fed whole flaxseed have a lower omega- 6 to omega3 fatty acids ratio in milk fat compared with those fed 
either micronized soybeans or calcium salts of palm oil (Petit, 2002), which would result in a healthier product for human consumption.

Feeding polyunsaturated fatty acids protected against ruminal biohydrogenation increases their proportion in milk (Kennelly, 1996; Tymchuk et al., 1998). The most common treatments are either chemical (e.g., formaldehyde) or physical (e.g., heating). Feeding a mixture of formaldehyde-treated ground canola seed and soybean has increased by 76 and $123 \%$, respectively, concentrations of linoleic and linolenic acids in milk fat (Tymchuk et al., 1998). Formaldehyde added to a mixture of casein and oil with a 1:10 ratio of formaldehyde to protein effectively increased the proportion of polyunsaturated fatty acids in milk (Bitman et al., 1975; Goering et al., 1977). Moreover, only 0.1 to 0.2 ppm of formaldehyde were found in the milk (Bitman et al., 1975). Whole flaxseed treated with $10 \%$ formaldehyde has been successful at increasing polyunsaturated fatty acids in milk (Petit et al., 2001), but the effective 1:10 formaldehyde to protein ratio could be reached by feeding only $2 \%$ formaldehyde in the DM of flaxseed, which represents the $0.25 \%$ formaldehyde limit allowed in the DM in Canada. Moreover, feeding whole oilseeds would be a less expensive option compared with treating oil with casein and formaldehyde as the latter requires more specialized equipments. Sunflower and flax are two alternative crops for farmers located in areas where they can not grow corn and the use of whole rather than ground seeds would be easier for on-farm feeding. The hypotheses were that formaldehyde treatment at the level allowed by Canadian regulations increases the proportion of polyunsaturated fatty acids in milk without any adverse effect on milk quality and feed utilization and that increases in milk concentration of polyunsaturated fatty acids would reflect the main polyunsaturated fatty acid contained in the seed (e.g., C18:2 for sunflower seed and C18:3 for flaxseed).

\section{MATERIALS AND METHODS}

The experiment was conducted at the Atlantic Dairy and Forage Institute of Frederiction Junction, NB, Canada, from April 2000 to December 2000 using 36 multiparous and four primiparous midlactating Holstein cows averaging $635 \mathrm{~kg}$ of $\mathrm{BW}(\mathrm{SE}=8 \mathrm{~kg})$. Cows were blocked within parity for similar calving dates. The experiment was conducted from wk 25 to 35 of lactation. Cows were housed in tie stalls, fed individually, and milked twice daily at 0615 and $1530 \mathrm{~h}$. Milk production was recorded at every milking. Cows within groups were assigned randomly to one of four treatments. The four dietary treatments (Table 1) consisted of supplements based on either untreated whole flaxseed (UNFLA), formalde- hyde-treated whole flaxseed (FOFLA), untreated whole sunflower seed (UNSUN), and formaldehyde-treated whole sunflower seed (FOSUN). The formaldehyde treatment was applied by adding $5.5 \mathrm{~g}$ of formalin (37\% formaldehyde) per $100 \mathrm{~g}$ of whole flaxseeds or sunflower seeds to create $\mathrm{pH}$ reversible methylene bridges within the seed. Concentration of formaldehyde was about $2.04 \%$ in the seed. There was $11.4 \%$ of formaldehydetreated flaxseed and $15.7 \%$ formaldehyde-treated sunflower in the diet (Table 2), which would lead to about 0.23 and $0.32 \%$ formaldehyde, respectively, in flaxseed and sunflower seed-based diets. Protected seeds were bagged and stored at ambient temperature. The four diets were designed to yield similar CP and ether extract concentrations and were formulated to meet requirements for cows that were $600 \mathrm{~kg}$ of BW producing $32 \mathrm{~kg} / \mathrm{d}$ of milk with $3.8 \%$ fat (NRC, 1989).

Diets were fed twice daily at 0600 and $1400 \mathrm{~h}$ for $10 \%$ orts. Feed consumption was recorded daily. Total mixed diets, silage, seeds, and protein supplement were sampled weekly, frozen, and composited on a 4-wk basis. Composited samples were mixed thoroughly and subsampled for chemical analyses. Milk samples were obtained weekly from each cow for two consecutive milkings and were analyzed separately to determine milk composition. Body weight of cows was determined weekly.

Blood was collected on wk 4 of the experiment $3 \mathrm{~h}$ postfeeding. Blood was withdrawn from the jugular vein into Vacutainer tubes (Becton Dickinson and Cie, Rutherford, NJ) containing EDTA for FFA, urea, and NEFA analyses in plasma. The plasma were separated and frozen at $-20^{\circ} \mathrm{C}$ for subsequent analysis. Milk samples were collected on wk 4 and 8 of the experiment from two consecutive milkings to determine fat and fatty acid composition in milk. Total feces were collected from all cows during wk 6 of the experiment for $7 \mathrm{~d}$. Feces and urine were acidified daily with $100 \mathrm{ml}$ of 10 $N \mathrm{H}_{2} \mathrm{SO}_{4}$, and they were mixed together thoroughly. A $10 \%$ subsample was taken and stored at $-15^{\circ} \mathrm{C}$ for subsequent drying at $55^{\circ} \mathrm{C}$. Milk samples were obtained from each cow for 14 consecutive milkings and were analyzed for $\mathrm{N}$ to estimate $\mathrm{N}$ balance.

\section{Chemical Analysis}

Dry matter of TMR was determined by drying at $100^{\circ} \mathrm{C}$ for $48 \mathrm{~h}$. Total $\mathrm{N}$ determination was done by the Kjeldahl method (AOAC, 1990). Both ADF and NDF were measured according to the nonsequential procedures of Van Soest et al. (1991). Plasma NEFA (kit 99075401; Wako Pure Chemical Industries, Osaka, Japan) and urea (kit No. 640-A, Sigma Diagnostic Inc., St. Louis, MO) concentrations were analyzed by colori- 
Table 1. Chemical composition of feed ingredients. ${ }^{1}$

\begin{tabular}{|c|c|c|c|c|c|c|}
\hline Item & Silage & Untreated flaxseed & Treated flaxseed & Untreated sunflower & Treated sunflower & Protein supplement ${ }^{2}$ \\
\hline $\mathrm{pH}$ & 4.17 & - & - & - & - & - \\
\hline $\mathrm{DM}(\%)$ & 41.9 & 90.8 & 91.6 & 90.9 & 90.8 & 89.3 \\
\hline $\mathrm{ADF}(\%)$ & 32.8 & 20.6 & 15.4 & 21.3 & 21.9 & - \\
\hline $\mathrm{CP}(\%$ of $\mathrm{DM})$ & 13.7 & 24.7 & 24.0 & 16.6 & 16.6 & 42.3 \\
\hline Ether extract (\% of DM) & 4.6 & 35.5 & 34.7 & 42.1 & 42.0 & - \\
\hline
\end{tabular}

${ }^{1}$ Mean of six 4-wk composite samples that were prepared from weekly samples.

${ }^{2} 40 \%$ Optima 200, Shur-Gain, Mississauga, ON, Canada.

metric methods. Nitrogen, fat, and lactose in milk were determined by infrared spectroscopy (Bentley 2000; Bentley Instrument, Inc. Chaska, MN) except for fat in milk samples collected on wk 4 and 8 , which were analyzed by the Roese-Goettlib method (AOAC, 1990). Ether extraction in feed ingredients and diets was conducted with a Soxlec system HT6 apparatus (Tecator, Fisher Scientific, Montreal, QC, Canada) according to the method No. 7.060 (AOAC, 1990).

Fatty acids were extracted and methylated according to the method described by Chouinard et al. (1997), while in situ transesterification was performed on feed ingredients according to Park and Goins (1994). Plasma fatty acids were extracted according to the procedures outlined by Delbecchi et al. (2001), and preparation of plasma fatty acid methyl esters was conducted as described by Folch et al. (1957). Fatty acid methyl ester profiles were measured by GLC on a Hewlett-Packard 6890 chromatograph (Hewlett-Packard Ltée, Montreal, QC, Canada) with a G1315A autosampler equipped with a flame ionization detector and a split-splitless injector as described by Delbecchi et al. (2001).

\section{Statistical Analysis}

All results were subjected to least squares ANOVA for a randomized complete block design. Data were ana-

Table 2. Ingredient and chemical composition of the experimental diets. ${ }^{1,2}$

\begin{tabular}{|c|c|c|c|c|}
\hline & FOFLA & FOSUN & UNFLA & UNSUN \\
\hline \multicolumn{5}{|l|}{ Ingredient, $\%$ of $\mathrm{DM}$} \\
\hline Grass silage & 51.5 & 51.1 & 51.6 & 51.3 \\
\hline Untreated flaxseed & 0 & 0 & 13.3 & 0 \\
\hline Formaldehyde-treated flaxseed & 11.4 & 0 & 0 & 0 \\
\hline Untreated sunflower & 0 & 0 & 0 & 15.2 \\
\hline Formaldehyde-treated sunflower & 0 & 15.7 & 0 & 0 \\
\hline $40 \%$ Optima $200^{3}$ & 4.2 & 6.8 & 4.3 & 6.8 \\
\hline Barley & 30.7 & 25.6 & 29.4 & 25.9 \\
\hline $\mathrm{CaCO}_{3}$ & 1.1 & 0.4 & 0.3 & 0.4 \\
\hline Mineral and vitamin premix ${ }^{4}$ & 1.1 & 0.4 & 1.1 & 0.4 \\
\hline \multicolumn{5}{|l|}{ Chemical } \\
\hline $\mathrm{DM}, \%$ & 52.9 & 56.1 & 52.9 & 52.4 \\
\hline $\mathrm{CP}, \%$ of $\mathrm{DM}$ & 15.9 & 15.5 & 15.9 & 15.8 \\
\hline Ether extract, \% of DM & 6.3 & 7.8 & 6.9 & 7.7 \\
\hline $\mathrm{NDF}, \%$ of DM & 40.0 & 39.0 & 39.9 & 41.5 \\
\hline $\mathrm{ADF}, \%$ of $\mathrm{DM}$ & 22.2 & 22.0 & 22.0 & 23.4 \\
\hline \multicolumn{5}{|l|}{ Fatty acids, $\%$ of total $^{5}$} \\
\hline $\mathrm{C} 16: 0$ & 5.5 & 5.8 & 5.2 & 5.9 \\
\hline C18:0 & 2.4 & 4.4 & 2.3 & 4.4 \\
\hline C18:1 & 21.4 & 14.5 & 23.8 & 14.6 \\
\hline C18:2 & 15.4 & 75.3 & 13.5 & 75.1 \\
\hline C18:3 & 55.3 & 0 & 55.2 & 0 \\
\hline
\end{tabular}

${ }^{1}$ FOFLA = supplement based on formaldehyde-treated whole flaxseed; FOSUN = supplement based on formaldehyde-treated whole sunflower seed; UNFLA = supplement based on untreated whole flaxseed; and UNSUN = supplement based on untreated whole sunflower seed.

${ }^{2}$ Mean of six monthly samples that were prepared by compositing weekly samples.

${ }^{3}$ OPTIMA $20040 \%$ CP, Shur-Gain, Mississauga, ON, Canada.

${ }^{4}$ Contained $14.0 \% \mathrm{Ca}, 5.0 \% \mathrm{P}, 3.9 \% \mathrm{Mg}, 10.0 \% \mathrm{Na}, 0.12 \% \mathrm{~S}, 1.4 \% \mathrm{~K}, 7.5 \% \mathrm{NaCl}, 1760 \mathrm{mg} / \mathrm{kg}$ of $\mathrm{Zn}, 85$ $\mathrm{mg} / \mathrm{kg}$ of I, $31 \mathrm{mg} / \mathrm{kg}$ of Co, $2850 \mathrm{mg} / \mathrm{kg}$ of Mn, $354 \mathrm{mg} / \mathrm{kg}$ of Cu, $2154 \mathrm{mg} / \mathrm{kg}$ of Fe, $15 \mathrm{mg} / \mathrm{kg}$ of Se, 385,701 $\mathrm{IU} / \mathrm{kg}$ of vitamin A, 85,500 IU/kg of vitamin D, and $1425 \mathrm{IU} / \mathrm{kg}$ of vitamin $\mathrm{E}$.

${ }^{5}$ Mean of seven daily samples that were collected during the digestibility trial. 
lyzed using a $2 \times 2$ factorial arrangement of treatments using the general linear models procedure of SAS (1991). Data on milk fatty acid composition were analyzed as a split-plot design with treatment, sampling time, and the interaction treatment by sampling time as main sources of variation. Data on milk production and composition, DMI, and BW were analyzed as repeated measurements using PROC MIXED of SAS (1991) and as mean values for the 10-wk experiment, when there was no interaction between week and treatment $(P>0.10)$. Treatment sum of squares were partitioned to provide orthogonal contrasts and compared: 1) flaxseed vs. sunflower seed, 2) formaldehyde-treated seeds vs. untreated seeds, and 3) the interaction between seed and formaldehyde treatment. Probability values greater than 0.10 were considered nonsignificant.

\section{RESULTS AND DISCUSSION}

Diets were designed to have similar chemical composition, but ether extract concentrations were slightly greater in sunflower than in flaxseed-based diets (Table 2 ). Concentrations of $\mathrm{CP}, \mathrm{NDF}$, and $\mathrm{ADF}$ were quite similar among diets. The C18:3 and C18:2 were, respectively, the main fatty acids in flaxseed and sunflower seed-based diets.

There was no interaction between week and treatment for any measurement. Therefore, only mean values for the 10-wk experiment are presented in the Tables. Intake of DM, expressed in kilograms per day, or as a percentage of BW, was significantly greater for cows fed flaxseed compared with those fed sunflower seeds (Table 3). Untreated whole flaxseed is readily accepted by dairy cows and has no negative effect on DMI (Petit et al., 2001, 2002; Petit, 2002). Moreover, feeding up to $30 \%$ of sunflower seed in the DM has no effect on DMI (Rafalowski and Park, 1982). Differences in DMI between sunflower seed and flaxseed could, however, be related to size of the seed. Flaxseed is smaller than sunflower seed, which could result in faster release from the rumen and less breakdown of the seed due to rumination with flaxseed than with sunflower seed. Feeding flaxseed compared with sunflower seed could then result in less oil being released in the rumen, which would limit the negative effect of oil on fiber digestion (Schauff and Clark, 1992) and thus on DMI. This would be corroborated by the fact that feeding $10 \%$ formaldehyde-treated flaxseed in the DM has no effect on ruminal fermentation (Petit et al., 2002), while feeding between 7.2 and $11.7 \%$ of sunflower seed does (Rafalowski and Park, 1982). Intake of DM, expressed in kilograms per day, was similar for cows fed treated and untreated seed, but when DMI was expressed as a percentage of BW, adding formaldehyde resulted in greater DMI by cows fed treated than untreated seed. However, feeding 5\% (Tymchuk et al., 1998) or $4.8 \%$ formaldehyde-treated canola seeds (Delbecchi et al., 2001) had no effect on DMI of dairy cows. Similarly, Crawford and Hoover (1984) reported no effect of feeding soybean meal treated with $0.3 \%$ formaldehyde, which represented about $0.035 \%$ of the DMI. Others (Troccon and Parrassin, 1980; Fiems et al., 1987) reported an increased DMI for diets containing formaldehyde-treated meals. Fluharty and Loerch (1989) found that treatment of corn with 1 or $2 \%$ formaldehyde had no effect on DMI of sheep, although formaldehyde reduced total tract digestion of DM and OM. Feeding barley treated with $0.11 \%$ formaldehyde had no effect on DMI or digestibility of DM and OM (McAllister et al., 1992), probably because of the low formaldehyde concentration. In most cases in which protection of lipid supplements against ruminal biohydrogenation improved feed intake, there was an increased fiber digestion in the rumen.

Milk production was similar for cows fed flaxseed and those fed sunflower. This would corroborate the fact that milk production of dairy cows is not affected by flaxseed (Petit, 2002) nor by feeding up to $30 \%$ of sunflower seed in the DM (Rafalowski and Park, 1982). Formaldehyde treatment of flaxseed and sunflower seed increased milk production by an average of 2.7 $\mathrm{kg} / \mathrm{d}$, which would mainly result of greater DMI when treating seeds with formaldehyde. Similar data were reported (Vérité and Journet, 1977; Madsen, 1982) when, respectively, a combination of formaldehydetreated soybean and cottonseed meals and of soybean and rapeseed meals were fed. On the other hand, formaldehyde treatment of supplement had no effect on milk yield of cows fed canola seeds (Ashes et al., 1992; Tymchuk et al., 1998) and soybean meal (Crawford and Hoover, 1984). Differences in the spectrum of available $\mathrm{AA}$ at the intestines that would be more consistent with AA needs for milk production could explain the difference in milk yield response when using different feed ingredients treated with formaldehyde. Greater milk production could be a result of greater dietary AA available for absorption by the animal. In fact, formaldehyde treatment of casein has increased DMI of lambs (Kempton and Leng, 1979) and digesta flow of dietary AA at the duodenal level (Kempton et al., 1979), which would contribute in improving animal production. Milk efficiency, expressed in kilograms of $4 \%$ FCM per kilogram of DMI, was increased by formaldehyde treatment (1.31 vs. 1.21 ), which agrees with the findings of Crawford and Hoover (1984) who used formaldehyde-treated soybean meal. Milk efficiency was greater with sunflower seed than with flaxseed (1.33 vs.1.21). Cows fed 
Table 3. Feed intake and milk production between wk 25 and 35 of lactation of Holstein cows fed supplements based on either untreated whole flaxseed (UNFLA), formaldehyde-treated whole flaxseed (FOFLA), untreated whole sunflower seed (UNSUN), or formaldehyde-treated whole sunflower seed (FOSUN). ${ }^{1}$

\begin{tabular}{|c|c|c|c|c|c|c|c|c|}
\hline & \multicolumn{5}{|c|}{ Treatment } & \multicolumn{3}{|c|}{ Probability } \\
\hline DMI, kg/d & 20.7 & 19.4 & 19.8 & 18.4 & 0.3 & 0.05 & 0.15 & 0.91 \\
\hline $\begin{array}{l}\text { Milk production, } \mathrm{kg} / \mathrm{d} \\
\text { Milk efficiency, } 4 \% \text { FCM/ }\end{array}$ & 24.9 & 25.8 & 22.4 & 23.0 & 0.6 & 0.52 & 0.03 & 0.90 \\
\hline $\begin{array}{l}\mathrm{kg} \text { of DMI } \\
\text { Milk composition, \% }\end{array}$ & 1.26 & 1.36 & 1.13 & 1.29 & 0.02 & 0.01 & 0.05 & 0.50 \\
\hline lactose & 4.49 & 4.56 & 4.36 & 4.46 & 0.04 & 0.27 & 0.11 & 0.80 \\
\hline $4 \%$ FCM, kg/d & 25.7 & 26.9 & 22.4 & 23.8 & 0.7 & 0.33 & 0.01 & 0.93 \\
\hline $\begin{array}{l}\text { Milk production, } \mathrm{kg} / \mathrm{d} \\
\text { protein }\end{array}$ & 082 & 080 & & & & & & \\
\hline fat & 1.06 & $\begin{array}{l}0.00 \\
1.12\end{array}$ & $\begin{array}{l}0.44 \\
0.90\end{array}$ & $\begin{array}{l}0.94 \\
0.98\end{array}$ & $\begin{array}{l}0.02 \\
0.03\end{array}$ & $\begin{array}{l}0.72 \\
0.30\end{array}$ & $\begin{array}{l}0.07 \\
0.02\end{array}$ & $\begin{array}{l}0.92 \\
0.86\end{array}$ \\
\hline lactose & 1.10 & 1.15 & 0.97 & 1.01 & 0.03 & 0.41 & 0.01 & 0.93 \\
\hline
\end{tabular}

${ }^{1}$ Least squares means with pooled standard error (SE).

flaxseed had greater DMI, expressed as a percentage of BW than those sunflower seed, but this did not result in greater $4 \% \mathrm{FCM}$ yield, thus leading to poorer milk efficiency.

Protein concentration in milk was greater for cows fed flaxseed compared with those fed sunflower seed. Flaxseed is smaller in size than sunflower seed, and that might have increased its rate of passage from the rumen and increased its supply of AA for milk protein synthesis. Differences in AA composition between sunflower and flaxseed might also affect milk protein synthesis. Flaxseed has increased milk protein concentration compared with micronized soybeans or Ca-salts of palm oil (Petit, 2002). Formaldehyde had no effect on protein concentration in milk. The lack of effect of the formaldehyde treatment on milk protein concentration has been previously reported by Tymchuk et al. (1998) and Ashes et al. (1992) when formaldehyde-treated canola seed was fed at 2 and $2.4 \%$ of dietary DM, respectively. On the other hand, Crooker et al. (1983) and Crawford and Hoover (1984) found that treating soybean meal with formaldehyde decreased milk protein concentration, which would be a result of insufficient supply of AA for milk production following a decrease in CP digestibility for treated meal. According to Crawford and Hoover (1984), increased milk protein concentration for cows fed formaldehyde-treated meals (Vérité and Journet, 1977) is usually a result of greater bypass of protein due to the formaldehyde treatment, which would increase AA availability at the intestine level. This would suggest that formadehyde treatment did not increase bypass of AA in the present experiment.
In the present study, concentrations of fat and lactose were similar among treatments. Treating seeds with formaldehyde increased production of milk protein, fat, and lactose, but there was no difference between cattle fed flaxseed and sunflower seed. Feeding formaldehydetreated canola seed at $6.5 \%$ of the total DMI has increased milk fat yield (Ashes et al., 1992). Generally, oils that were effectively protected against ruminal biohydrogenation increase milk fat yield (Ashes et al., 1992). On the other hand, ineffective protection (Petit et al., 2002), or low level of added fat (Tymchuk et al., 1998), had no effect on milk fat yield. Production of $4 \%$ FCM was similar for cows fed flaxseed and sunflower seed, but it was greater for cows fed formaldehydetreated seeds. Initial, final, and average BW were similar among treatments (Table 3). Change in BW was not affected by the diet.

In general, with the exception of $\mathrm{C} 18: 2 \mathrm{t} 6$, which formaldehyde treatment tended to decrease $(P<0.07)$, formaldehyde had limited effect on milk fatty acid composition (Table 4). This would suggest that formaldehyde was not very effective in protecting polyunsaturated fatty acids against ruminal biohydrogenation. This is in disagreement with the results of Tymchuk et al. (1998), who reported that formaldehyde treatment significantly increased C18:2 and C18:3 concentrations in milk by 76 and $123 \%$, respectively. Discrepancies between experiments when feeding formaldehyde-treated oilseed could result in the technique being used to apply formaldehyde. Tymchuk et al. (1998) used an encapsulation process while formaldehyde was sprayed in the present experiment, and that could have resulted in 
Table 4. Average milk fatty acid composition of Holstein cows fed between wk 25 and 35 of lactation supplements based on either untreated whole flaxseed (UNFLA), formaldehyde-treated whole flaxseed (FOFLA), untreated whole sunflower seed (UNSUN), or formaldehyde-treated whole sunflower seed (FOSUN). ${ }^{1}$

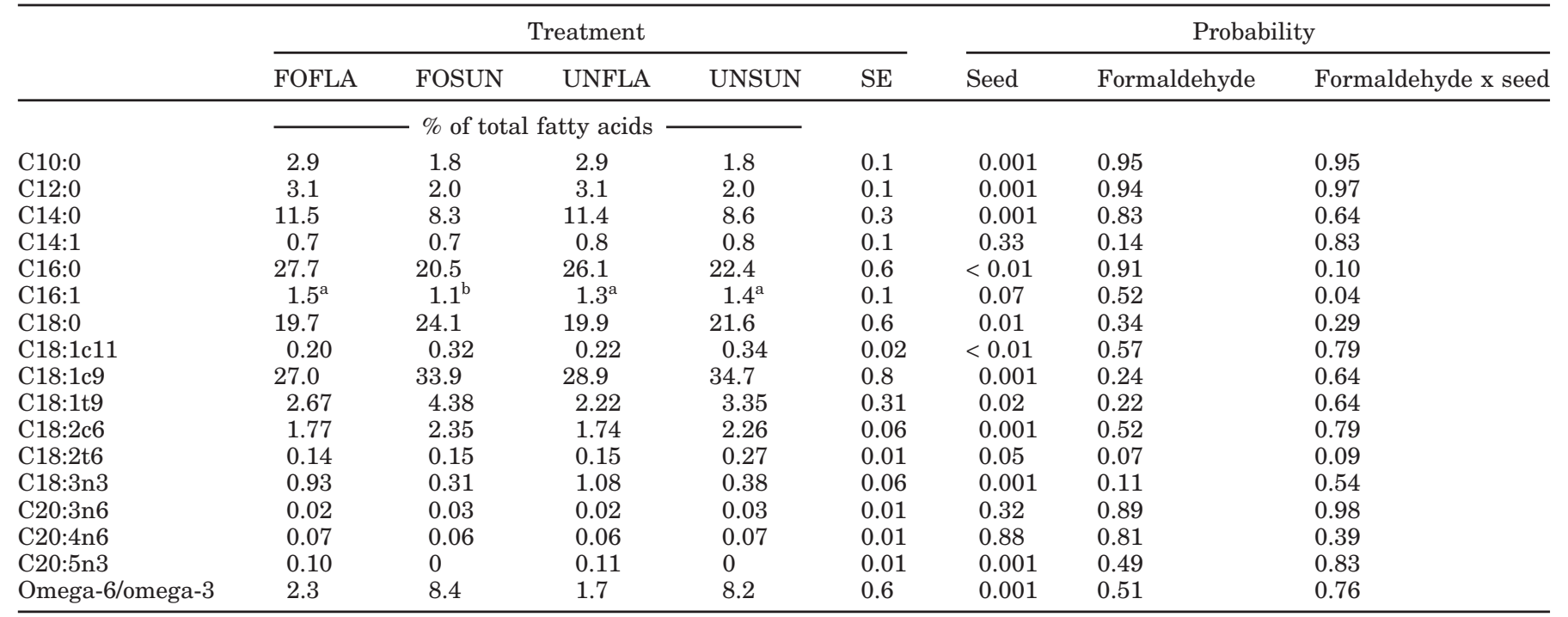

${ }^{1}$ Least squares means with pooled standard error (SE).

${ }^{\mathrm{a}, \mathrm{b}}$ Means within a row with a different subscript differs $(P<0.05)$.

lower protection of fatty acids against ruminal biohydrogenation. Feeding flaxseed compared with sunflower seed increased concentrations of C10:0, C12:0, C14:0, $\mathrm{C} 16: 0, \mathrm{C} 18: 3 \mathrm{n} 3$, and C20:5n 3 and decreased those of C18:0, C18:1c11, C18:1c9, C18:1t9, and C18:2c6. Although dietary concentration of C18:1 was greater on flaxseed than on sunflower diets, concentrations of $\mathrm{C} 18: 1 \mathrm{c} 11, \mathrm{C} 18: 1 \mathrm{c} 9$, and $\mathrm{C} 18: 1 \mathrm{t} 9$ in milk were not increased, which could result of lower apparent digestibility of ether extract for cows fed the former diets. Feeding formaldehyde-treated sunflower seeds resulted in the lowest C16:1 concentration in milk fat. Feeding untreated sunflower seeds tended $(P=0.09)$ to increase concentration of C18:2t6 compared to feeding the other diets. Concentrations of C14:1, C20:3n6, and C20:4n6 were similar among treatments. The omega 6 to omega 3 fatty acids ratio in milk was significantly reduced by feeding flaxseed compared with sunflower seed, which would improve the nutritive value of milk from a human health point of view. According to Sim (1998), the current high ratio should be decreased to less than 4 to 1 to reduce the potential risk of coronary heart diseases; feeding whole flaxseed to dairy cows could contribute in improving human health by a greater intake of omega 3 fatty acids in enriched dairy products. In general, composition of milk fatty acids of cows fed flaxseedbased diets was similar to those reported by Petit et al. (2001) who compared formaldehyde-treated flaxseed and Megalac and with those of Kennelly and Khorasani (1992), who fed up to $15 \%$ of flaxseed in the total DM of dairy cows. Milk fatty acid composition generally reflected fatty acid composition of oilseeds that were fed to dairy cows (Table 2), with C18:0 and C18:2 being the most predominant fatty acids on sunflower-based diets.

During the digestibility trial, DMI, milk yield, and $4 \%$ FCM yield were similar for cows fed flaxseed and sunflower seed but were greater for cows fed formaldehyde-treated than untreated seeds (Table 5). Apparent digestibility of DM was not affected by seed but was greater for cows fed formaldehyde-treated seeds, which would have contributed in increasing DMI, expressed as a percentage of BW, of cows fed the treated seeds (Table 3). Apparent digestibilities of $\mathrm{CP}$ and ether extract were higher for cows fed sunflower than for those fed flaxseed-based diets. Formaldehyde treatment had no effect on apparent digestibility of $\mathrm{CP}$ and ether extract. Lower ether extract apparent digestibility for cows fed formaldehyde-treated flaxseed compared with those fed Megalac or micronized soybeans has been reported by Petit et al. (2002). Fluharty and Loerch (1989) found that $\mathrm{N}$ digestibility was reduced when corn was treated with 1 or $2 \%$ formaldehyde, but McAllister et al. (1992) reported that treatment of barley with $0.11 \%$ formaldehyde did not affect $\mathrm{N}$ digestion or the amount of $\mathrm{N}$ retained. Fiems et al. (1987) observed no difference in OM digestibility by calves fed diets with untreated or soybean meal treated with $0.2 \%$ formaldehyde, which was close to the 0.25 to $0.30 \%$ concentration applied to oilseeds in the present experiment. This would suggest that the optimum level of formaldehyde required to improve $\mathrm{N}$ utilization would be between 0.5 
Table 5. Feed intake and digestibility on wk 30 of lactation of Holstein cows fed supplements based on either untreated whole flaxseed (UNFLA), formaldehyde-treated whole flaxseed (FOFLA), untreated whole sunflower seed (UNSUN), or formaldehyde-treated whole sunflower seed (FOSUN). ${ }^{1}$

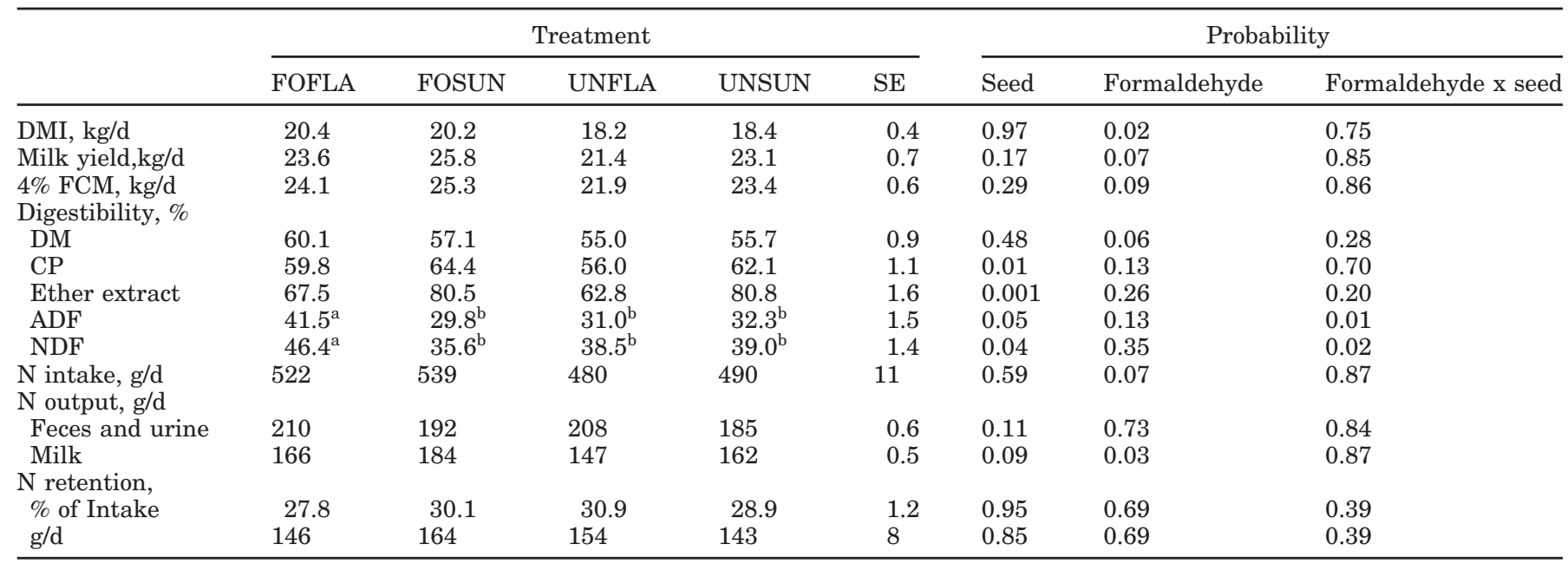

${ }^{1}$ Least squares means with pooled standard error (SE).

${ }^{\mathrm{a}, \mathrm{b}}$ Means within a row with a different subscript differs $(P<0.05)$.

to $1.0 \%$ of the treated-supplement fed. There was an interaction between formaldehyde treatment and seed for apparent digestibilities of ADF and NDF, which would have contributed in increasing DM apparent digestibility of formaldehyde-treated diets; cows fed formaldehyde-treated flaxseed had the greatest apparent digestibilities compared with those fed the other diets, which were similar. Feeding protected fat sources such as calcium salts of fatty acids (Schauff and Clark, 1992) are known to improve fiber digestion, which could have contributed to increase fiber digestion of formaldehydetreated flaxseed. In fact, formaldehyde-treated flaxseed fed at $10 \%$ of the DM has no effect of ruminal fermentation (Petit et al., 2002), while sunflower seed does when fed between 7.2 to $11.7 \%$ of the DM (Rafalowski and Park, 1982). Flaxseed is smaller than sunflower seed, which could result in faster release from the rumen and less breakdown of the seed due to rumination with flaxseed. Feeding flaxseed compared to sunflower seed could then result in less oil being released in the rumen, which would limit the negative effect of oil on fiber digestion (Schauff and Clark, 1992) and thus on DMI. In fact, Ivan et al. (2001) have shown that sunflower seed oil modifies ruminal fermentation.

Intake of $\mathrm{N}$ was similar for flaxseed and sunflower seed-based diets (Table 4), but formaldehyde treatment increased $(P=0.07)$ intake of $\mathrm{N}$. Output of $\mathrm{N}$ in feces and urine, expressed in grams per day, was similar for cows fed flaxseed compared with those fed sunflower seed and formaldehyde addition had no effect. Output of $\mathrm{N}$ in milk, expressed in grams per day, tended to be greater $(P=0.09)$ for cows fed sunflower seed than for those fed flaxseed. Adding formaldehyde increased $\mathrm{N}$ output in the milk of cows fed treated compared with untreated seeds probably as a result of greater $\mathrm{N}$ intake for cows on treated diets. Retention of N, expressed as a percentage of intake or expressed in grams per day, was similar among treatments.

Apparent digestibilities of C16:0, C18:0, C18:1c11, $\mathrm{C} 18: 1 \mathrm{c} 9, \mathrm{C} 18: 2 \mathrm{c} 6$, and $\mathrm{C} 18: 3 \mathrm{n} 3$ were significantly greater for cows fed sunflower seed than for those fed flaxseed (Table 6), which would agree with the greater ether extract apparent digestibility for the former (Table 4). Apparent digestibility of C18:0 was negative for all treatments. In the present experiment, all four diets were high in concentrations of $\mathrm{C} 18: 2$ and $\mathrm{C} 18: 3$ (Table 2 ), and it is known that the input to the intestinal pool of C18:0 is of dietary origin or results from the extensive ruminal biohydrogenation of dietary polyunsaturated fatty acids (Kalscheur et al., 1997). Therefore, ruminal biohydrogenation of these fatty acids would have increased their concentrations in the feces, thus leading to negative apparent digestibility values for C18:0 as previously reported by Romo et al. (2000). Fatty acid apparent digestibility is thought to increase with the degree of unsaturation. According to Doreau and Ferlay (1994), apparent digestibility of 18-carbon fatty acids is greater for acids with one or two double bonds, although apparent digestibilities of both $\mathrm{C} 18: 2$ and $\mathrm{C} 18: 3$ were very high in the present experiment and very similar within a given treatment. Formaldehyde treatment had no effect on apparent digestibility of individual fatty acids, corroborating the lack of any effect of formaldehyde on composition of fatty acids in milk and in blood. 
Table 6. Apparent digestibility of fatty acids on wk 30 of lactation by Holstein cows fed supplements based on either untreated whole flaxseed (UNFLA), formaldehyde-treated whole flaxseed (FOFLA), untreated whole sunflower seed (UNSUN), or formaldehyde-treated whole sunflower seed (FOSUN). ${ }^{1}$

\begin{tabular}{|c|c|c|c|c|c|c|c|c|}
\hline & \multicolumn{5}{|c|}{ Treatment } & \multicolumn{3}{|c|}{ Probability } \\
\hline & FOFLA & FOSUN & UNFLA & UNSUN & SE & Seed & Formaldehyde & Formaldehyde x seed \\
\hline & & 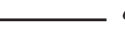 & $\%$ & 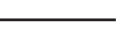 & & & & \\
\hline C16:0 & 58.2 & 85.1 & 54.9 & 84.2 & 2.5 & 0.001 & 0.24 & 0.50 \\
\hline C18:0 & -495.8 & -294.8 & -657.3 & -283.7 & 38.7 & 0.001 & 0.21 & 0.15 \\
\hline C18:1c11 & 32.9 & 97.5 & 35.2 & 93.9 & 5.8 & 0.001 & 0.88 & 0.49 \\
\hline C18:1n9c & 59.8 & 95.5 & 56.4 & 95.3 & 3.4 & 0.001 & 0.45 & 0.50 \\
\hline C18:2n6c & 90.5 & 99.1 & 90.7 & 98.9 & 0.8 & 0.001 & 0.95 & 0.76 \\
\hline C18:3n3 & 91.2 & 98.5 & 90.8 & 98.4 & 0.7 & 0.001 & 0.70 & 0.88 \\
\hline
\end{tabular}

${ }^{1}$ Least squares means with pooled standard error (SE).

Blood urea $\mathrm{N}$ concentration was similar among treatments (Table 7). Lower urea $\mathrm{N}$ concentration in blood is usually reported when formaldehyde treatment effectively decreased N degradability (Sharma et al., 1972), suggesting that treatment in the present experiment did not protect protein against ruminal degradation. This would corroborate the lack of effect of formaldehyde treatment on milk fatty acid composition as protection of protein is usually paralleled with that of fat as the protein-rich matrix surrounds the fat droplets of oilseeds (Khorasani et al., 1992). Blood NEFA concentrations were significantly lower for cows fed flaxseed compared with those fed sunflower seed. Greater NEFA concentrations have been previously reported for cows fed Megalac compared to those fed formaldehydetreated flaxseed (Petit et al., 2001). Formaldehyde treatment had no effect on blood concentration of NEFA, which would suggest that formaldehyde was not very protective in preventing ruminal biohydrogenation in the rumen in the present experiment. Blood concentration of NEFA usually is (Goering et al., 1977) or tended (Oldham et al., 1982), respectively, to be greater for dairy cows fed protected oil sources or casein, which could result in numerically (Goering et al., 1977) or significant (Oldham et al., 1982) lower DMI. Lower DMI leads to greater body fat mobilization and greater blood concentration of NEFA (Roberts et al., 1981).

Blood concentrations of fatty acids were mainly affected by seed. Concentrations of C14:0, C16:0, $\mathrm{C} 18: 1 \mathrm{c} 11, \mathrm{C} 18: 3 \mathrm{n} 3$, and C20:5n3 were increased by feeding flaxseed rather than sunflower seed and those of C18:1t9, C18:2c6, C18:2t6, and C18:3n6 were decreased

Table 7. Blood composition of Holstein cows fed between week 25 and 35 of lactation supplements based on either untreated whole flaxseed (UNFLA), formaldehyde-treated whole flaxseed (FOFLA), untreated whole sunflower seed (UNSUN), or formaldehyde-treated whole sunflower seed (FOSUN). ${ }^{1}$

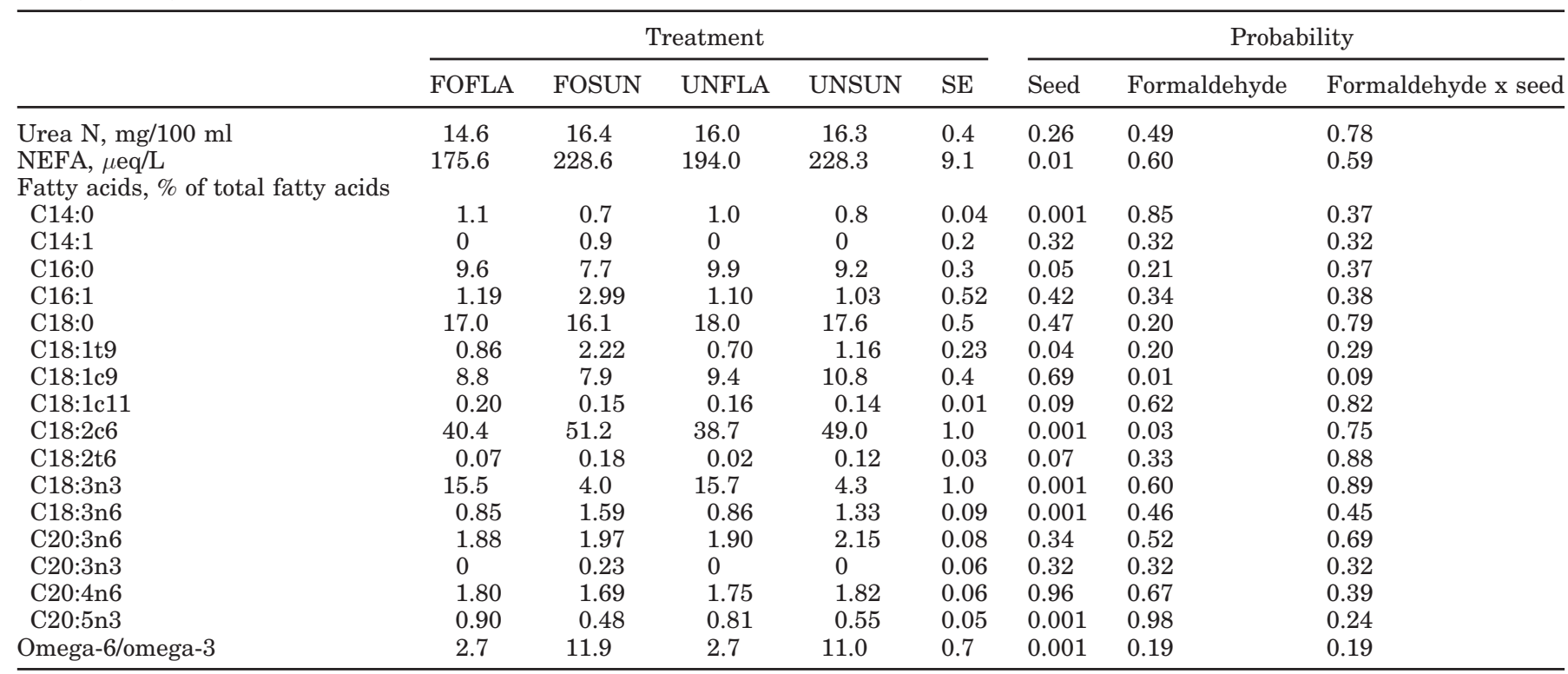

\footnotetext{
${ }^{1}$ Least squares means with pooled standard error (SE).
} 
(Table 7). Formaldehyde treatment of seed resulted in greater concentrations of $\mathrm{C} 18: 1 \mathrm{c} 9(P=0.01)$ and C18:2c6 $(P=0.03)$ in blood compared with untreated seed. Feeding untreated sunflower seed resulted in the highest concentration of $\mathrm{C} 18: 1 \mathrm{c} 9$ in blood. There was no difference among treatments for blood concentrations of C14:1, C16:1, C18:0, C20:3n6, C20:3n3, and C20:4n6. Feeding flaxseed rather than sunflower seed significantly decreased the omega 6 to omega 3 ratio in blood. Lower omega 6 to omega 3 ratio in blood have been previously reported for cows fed sources of omega 3 fatty acids such as whole flaxseed (Petit, 2002) and formaldehyde-treated flaxseed or fish oil (Petit et al., 2002).

\section{CONCLUSIONS}

Feeding whole flaxseed instead of sunflower increased DMI. Intake of DM, expressed as a percentage of BW, was increased by adding formaldehyde to oilseeds, although there was no difference when DMI was expressed in kilogram per day. Milk production was similar for cows fed flaxseed and those fed sunflower, suggesting that both oilseeds are acceptable fat sources and that flaxseed and sunflower seed can substitute each other in the diet of midlactating dairy cows. However, milk efficiency was greater with sunflower seed than with flaxseed. Treating sunflower seed and flaxseed with about $2.04 \%$ of formaldehyde increased milk production by an average of $2.65 \mathrm{~kg} / \mathrm{d}$. Protein concentration in milk was greater for cows fed flaxseed than for those fed sunflower seed and formaldehyde had no effect. In general, formaldehyde treatment had limited effect on milk fatty acid composition, suggesting that formaldehyde was not very effective in protecting polyunsaturated fatty acids against ruminal biohydrogenation. Feeding flaxseed resulted in the lowest omega 6 to omega 3 fatty acid ratio, which would improve the nutritive value of milk from a human health point of view. Formaldehyde treatment of flaxseed and sunflower seed would be effective in increasing feed intake, milk production, and milk efficiency of midlactating dairy cows, although it had no effect on milk fatty acid composition.

\section{ACKNOWLEDGMENTS}

The authors thank N. Clark, J. Sweetland, L. Veilleux, and S. Dallaire for technical assistance and the Atlantic Dairy and Forage Institute, Fredericton Junction, NB E5L 1R1 and Shur-Gain, QC L5R 3E7 for their financial help. This project was sponsered in part by the Matching Investment Initiative of Agriculture and Agri-Food Canada.

\section{REFERENCES}

Association of Official Analytic Chemists. 1990. Official Methods of Analysis. 15th ed. AOAC, Arlington, VA.

Ashes, J. R., P. St. Vincent Welch, S. K. Gulati, T. W. Scott, G. H. Brown, and S. Blakelyel. 1992. Manipulation of the fatty acid composition of milk by feeding protected canola seeds. J. Dairy Sci. 75:1090-1096.

Bitman, J., T. R. Wrenn, D. L. Wood, G. C. Mustakas, E. C. Baker, and W. J. Wolf. 1975. Effects of feeding formaldehyde treated, full fat soybean flours on milk fat polyunsaturated fatty acids. J. Am. Oil Chem. Soc. 52:415-418.

Casper, D. P., D. J. Schingoethe, and W. A. Eisenbeisz. 1990. Response of early lactation cows to diets that vary in ruminal degradability of carbohydrates and amount of fat. J. Dairy Sci. 73:425-444.

Chouinard, P. Y., V. Girard, and G. J. Brisson, 1997. Performance and profiles of milk fatty acids of cows fed full-fat, heat-treated soybeans using various processing methods. J. Dairy Sci. 80:334-342.

Crawford, R. J., Jr., and W. H. Hoover. 1984. Effects of particle size and formaldehyde treatment of soybean meal on milk production and composition for dairy cows. J. Dairy Sci. 67:1945-1952.

Crooker, B. A., J. H. Clark, and R. D. Shanks. 1983. Effects of formaldehyde treated soybean meal on milk yield, milk composition, and nutrient digestibility in the dairy cow. J. Dairy Sci. 66:492-504.

Delbecchi, L., C. E. Ahnadi, J. J. Kennelly, and P. Lacasse. 2001. Milk fatty acid composition and mammary lipid metabolism in Holstein cows fed protected or unprotected canola seeds. J. Dairy Sci. 84:1375-1381.

Doreau, M., and A. Ferlay. 1994. Digestion and utilisation of fatty acids by ruminants. Anim. Feed Sci. Technol. 45:379-396.

Fiems, L. O., B. G. Cottyn, CH. V. Bocque, and F. X. Buysse. 1987. Effect of formaldehyde-treated soya bean meal and urea in starter on nitrogen quality, degradability in sacco, sheep digestibility and calf performance. Anim. Feed Sci. Technol. 16:287-295.

Fluharty, F. L., and S. C. Loerch. 1989. Chemical treatement of ground corn to limit ruminal starch digestion. Can. J. Anim. Sci. 69:173-180.

Folch, J., M. Lees, and G. H. Sloane-Stanley. 1957. A simple method for the isolation and purification of total lipids from animal tissues. J. Biol. Chem. 226:497-509.

Goering, H. K., T. R. Wrenn, L. F. Edmondson, J. R. Weyant, D. L. Wood, and J. Bitman. 1977. Feeding polyunsaturated vegetable oils to lactating cows. J. Dairy Sci. 60:739-747.

Ivan, M., P. S. Mir, K. M. Koenig, L. M. Rode, L. Neill, T. Entz, and Z. Mir. 2001. Effects of dietary sunflower seed oil on rumen protozoa population and tissue concentration of conjugated linoleic acid in sheep. Small Rum. Res. 41:215-227.

Kalscheur, K. F., B. B. Teter, L. S. Piperova, and R. A. Erdman. 1997. Effect of fat source on duodenal flow of trans-C18:1 fatty acids and milk fat production in dairy cows. J. Dairy Sci. 80:2115-2126.

Kempton, T. J., and R. A. Leng. 1979. Protein nutrition of growing lambs. 1. Responses in growth and rumen function to supplementation of a low-protein-cellulosic diet with either urea, casein or formaldehyde-treated casein. Br. J. Nutr. 42:289-302.

Kempton, T. J., J. V. Nolan, and R. A. Leng. 1979. Protein nutrition of growing lambs. 2. Effect of nitrogen digestion of supplementing a low-protein-cellulosic diet with either urea, casein, or formaldehyde-treated casein. Br. J. Nutr. 42:303-315.

Kennelly, J. J. 1996. The fatty acid composition of milk as influenced by feeding oilseeds. Anim. Feed Sci. Technol. 60:137-152.

Kennelly, J. J., and R. G. Khorasani. 1992. Influence of flaxseed feeding on the fatty acid composition of cow's milk. Pages 99-105 in Proc., 54th Flax Inst. Conf., J. F. Carter, ed. North Dakota State Univ., Fargo.

Kim, J. K., D. J. Schingoethe, D. P. Casper, and F. C. Ludens. 1993. Supplemental dietary fat from extruded soybeans and calcium soaps of fatty acids for lactating dairy cows. J. Dairy Sci. 76:197-204.

Khorasani, G. R., G. De Boer, P. H. Robinson, and J. J. Kennelly. 1992. Effect of canola fat on ruminal and total tract digestion, 
plasma hormones, and metabolites in lactating dairy cows. J. Dairy Sci. 75:492-501.

Madsen, J. 1982. The effects of formaldehyde-treated protein and urea on milk yield and composition in dairy cows. Acta Agric. Scand. 32:389-395.

McAllister, T. A., K. A. Beauchemin, L. A. McClelland, and K.-J. Cheng. 1992. Effect of formaldehyde-treated barley or escape protein on nutrient digestibility, growth and carcass traits of feedlot lambs. Can. J. Anim. Sci. 72:309-316.

National Research Council. 1989. Nutrient Requirements of Dairy Cattle. 6th rev. ed. Natl. Acad. Sci., Washington, DC.

Oldham, J. D., I. C. Hart, and J. A. Bines. 1982. Formaldehyde-treated proteins for dairy cows-effects on blood hormone concentrations. Br. J. Nutr. 48:543-547.

Palmquist, D. L., and T. C. Jenkins. 1980. Fat in lactation rations: A review. J. Dairy Sci. 63:1-14.

Park, P. W., and R. E. Goins. 1994. In situ preparation of fatty acid methyl esters for analysis of fatty acid composition in foods. J. Food Sci. 59:1262-1266.

Petit, H. V., R. J. Dewhurst, J. G. Proulx, M. Khalid, W. Haresign, and H. Twagiramungu. 2001. Milk production, milk composition, and reproductive function of dairy cows fed different fats. Can. J. Anim. Sci. 81:263-271.

Petit, H. V., R. J. Dewhurst, N. D. Scollan, J. G. Proulx, M. Khalid, W. Haresign, H. Twagiramungu, and G. E. Mann. 2002. Milk production and composition, ovarian function, and prostaglandin secretion of dairy cows fed omega-3 fats. J. Dairy Sci. 85:889-899.

Petit, H. V. 2002. Digestion, milk production, milk composition, and blood composition of dairy cows fed whole flaxseed. J. Dairy Sci. 85:1482-1490.

Rafalowski, W., and C. S. Park. 1982. Whole sunflower seed as a fat supplement for lactating cows. J. Dairy Sci. 65:1484-1492.

Roberts, C. J., I. M. Reid, G. J. Rowlands, and A. Patterson. 1981. A fat mobilisation syndrome in dairy cows in early lactation. Vet. Rec. 108:7-9.
Romo, G. A., R. A. Erdman, B. B. Teter, J. Sampugna, and D. P. Casper. 2000. Milk composition and apparent digestibilities of dietary fatty acids in lactating dairy cows abomasally infused with cis or trans fatty acids. J. Dairy Sci. 83:2609-2619.

SAS/STAT User's Guide, Version 6, 4th ed. 1991. SAS Institute, Inc., Cary, NC.

Schauff, D. J., and J. H. Clark. 1992. Effects of feeding diets containing calcium salts of long-chain fatty acids to lactating dairy cows. J. Dairy Sci. 75:2990-3002.

Schingoethe, D. J., M. J. Brouk, K. D. Lightfield, and R. J. Baer. 1996. Lactational responses of dairy cows fed unsaturated fat from extruded soybeans or sunflower seeds. J. Dairy Sci. 79:1244-1249.

Sharma, H. R., J. R. Ingalls, and J. A. McKirdy. 1972. Nutritive value of formaldehyde-treated rapeseed meal for dairy calves. Can. J. Anim. Sci. 52:363-371.

Sim, J. S. 1998. Designer eggs and their nutritional and functional significance. World Rev. Nutr. Diet. 23:89-101.

Stegeman, G. A., d. P. Casper, d. J. Schingoethe, and R. J. Baer. 1992. Lactational responses of dairy cows fed unsaturated dietary fat and receiving bovine somatotropin. J. Dairy Sci. 75:1936-1945.

Troccon, J. L., and P. R. Parrassin. 1980. Influence du tannage du tourteau d'arachide sur les performances de veaux d'élevage de race Montbéliarde de la naissance à 3 mois. Bull. Tech. CRZV 42:5-8.

Tymchuk, S. M., G. R. Khorasani, and J. J. Kennelly. 1998. Effect of feeding formaldehyde- and heat-treated oil seed on milk yield and milk composition. Can. J. Anim. Sci. 78:693-700.

Van Soest, P. J., J. B. Robertson, and B. A. Lewis. 1991. Methods for dietary fiber, neutral detergent fiber, and nonstarch polysaccharides in relation to animal nutrition. J. Dairy Sci. 74:35833597.

Vérité, R., and M. Journet. 1977. Utilisation des tourteaux traités au formol par les vaches laitières. II. Effets sur la production laitière du traitement des tourteaux et du niveau d'apport azoté au début de la lactation. Ann. Zootech. 26:183-205. 